\title{
Genetic diversity of ribosomal loci (5S and 45S rDNA) and pSc119.2 repetitive DNA sequence among four species of Aegilops (Poaceae) from Algeria
}

\author{
Nourdine BAIK ${ }^{1,2} *$ (D), Houda BANDOU ${ }^{2}$, Miriam GONZALEZ GARCIA ${ }^{3}$ (D), Elena BENAVENTE ${ }^{4}$ (D), \\ Juan Manuel VEGA ${ }^{3}$ (D) \\ ${ }^{1}$ Laboratory of Valorization of Vegetal Resource and Food Security in Semi-Arid Areas, South West of Algeria, Department of \\ Biology, Faculty Science of Nature and Life, Tahri Mohammed University of Bechar, Algeria \\ ${ }^{2}$ Laboratoire de biologie et Physiologie des Organismes (LBPO), Faculté des Sciences Biologiques, Université des Sciences et de \\ la Technologie Houari Boumediene (USTHB), Alger, Algérie \\ ${ }^{3}$ Departamento de Genética, Fisiología y Microbiología, Facultad de Biología, Universidad Complutense, Madrid, Spain \\ ${ }^{4}$ Departamento de Biotecnología-Biología Vegetal, Escuela Técnica Superior de Ingenieros Agronomos, Universidad Politécnica, \\ Madrid, Spain
}

\begin{abstract}
In continuation of our previous research we carried out the karyological investigation of 53 populations of four Aegilops species (A. geniculata, A. triuncialis, A. ventricosa, and A. neglecta) sampled in different eco-geographical habitats in Algeria. The genetic variability of the chromosomal DNA loci of the same collection of Aegilops is highlighted by the Fluorescence In Situ Hybridization technique (FISH) using three probes: 5S rDNA, 45S rDNA, and repetitive DNA (pSc119.2). We found that the two rDNA loci (5S and 45S) hybridized with some chromosomes and showed a large genetic polymorphism within and between the four Aegilops species, while the repetitive DNA sequences (pSc119.2) hybridized with all chromosomes and differentiated the populations of the mountains with a humid bioclimate from the populations of the steppe regions with an arid bioclimate. However, the transposition of the physical maps of the studied loci (5S rDNA, 45S rDNA, and pSc119.2) with those of other collections revealed the existence of new loci in Aegilops from Algeria.
\end{abstract}

Keywords: Aegilops, Algeria, cytogenetic markers, eco-geography, genetic diversity, plant genetic resources

Article history. Submitted 14 July 2021. Received revised 19 November 2021. Published 31 December 2021

Citation. Baik N., Bandou H., Gonzalez Garcia M., Benavente E., Vega J.M. 2021. Genetic diversity of ribosomal loci (5S and 45S rDNA) and pSc119.2 repetitive DNA sequence among four species of Aegilops (Poaceae) from Algeria. Ukrainian Botanical Journal, 78(6): 414-425. https://doi.org/10.15407/ukrbotj78.06.414

*Corresponding author (e-mail: baik.nourdine@univ-bechar.dz)

\section{Introduction}

The genus Aegilops L., belonging to family Poaceae, tribe Triticeae, subtribe Triticineae Griseb., includes about 22 annual self-fertile species (Van Slageren, 1994' see also POWO, 2021: https://powo.science.kew.org/ taxon/17369-1). It represents the main genetic reserve and a very important genetic resource for the breeding and improvement of cultivated wheat, Triticum L. spp. (Kilian et al., 2011). Therefore, an accurate genetic characterization of these species is desirable.

(C) 2021 N. Baik, H. Bandou, Gonzalez M. Garcia, E. Benavente, J.M. Vega. Published by the M.G. Kholodny Institute of Botany, NAS of Ukraine. This is an open access article under the terms of the Creative Commons Attribution License (http://creativecommons.org/licenses/by/4.0/), which permits use, distribution, and reproduction in any medium, provided the original work is properly cited 
Cytogenetic studies of Aegilops species have been often used to clarify the systematic and phylogenetic position of certain taxa (Senyaninova-Korchagina, 1932; Chennaveeraiah, 1960; Kimber, Feldman, 1987; Van Slageren, 1994). As it comes out from these results, the diploid species of Aegilops represent seven genome types: C (A. markgrafii (Greuter) K.Hammer), M (A. comosa Sm.), N (A. uniaristata Steud.), D (A. tauschii Coss.), U (A. umbellulata Zhuk.), T (A. mutica Boiss.), and $\mathrm{S}$ (A. speltoides Tausch, A. bicornis (Forssk.) Jaub. \& Spach, A. longissima Schweinf. \& Muschl., A. sharonensis Eig, and A. searsii Feldman \& Kislev). Indeed, the allopolyploid species possess different combinations of these genomes.

Previously, Badaeva et al. (1996, 2002, 2004, 2011) established the phylogenic relationships between polyploid species and their diploid parents by C-banding and cytomolecular techniques. They found that in the majority of polyploid Aegilops species, the genome is variously modified as compared to their ancestors. However, other molecular approaches have been developed, such as the study of reserved proteins (Fernandez-Calvin, Orellana, 1990; Rodriguez-Quijano et al., 2000; Sun et al., 2006) and DNA polymorphism (Zhang et al., 1996; Zaharieva et al., 2001; Sasanuma et al., 2004; Salina et al., 2006; Haider et al., 2008; Mahjoub et al., 2010; Giraldo et al., 2016) for better knowledge of speciation processes and genomic evolution in these species.

The main objective of the present research was to evaluate the genetic diversity of Aegilops populations sampled in a large range of ecological conditions in northern Algeria, using a cytogenetic approach based on analysis of the chromosomes structure by FISH. Moreover, the role of ecological factors in the differentiation and evolution of chromosomes and species is also discussed.

\section{Materials and Methods}

\section{Plant materials}

The collections used in these experiments are as follows: thirty-five populations of $A$. geniculata, eight of A. neglecta, six of $A$. ventricosa, and four of $A$. triuncialis, sampled from May 2012 to July 2015, according to an east-west rainfall gradient and north-south aridity gradient in Algeria (Fig. 1).

Each sampling site was characterized by the main ecological factors of the Mediterranean climate as the average annual rainfall $(\mathrm{P})$, average temperatures of the hottest month in summer (M), average temperatures of the coldest month in winter (m), altitude (Alt), and the bioclimatic coefficient (Q2) (Table 1). At each sampling site, ten individuals were randomly sampled (each separated from another sample by at least one meter) for cytogenetic study (FISH).

\section{Chromosome preparations}

Chromosome preparations were made according to González-García et al. (2011), with some modifications. After seeds germination in Petri dishes at the room temperature, the roots of 1.0 to $1.5 \mathrm{~cm}$ were cut and pretreated by ice-cold water for $48 \mathrm{hrs}$. Fixation and conservation were made in a mixture alcohol-acetic acid $(3: 1)$ at $4{ }^{\circ} \mathrm{C}$. Roots maceration was carried out in following mixture of enzymes: cytohelicase $1 \%$, pectolyase $1 \%$, and cellulase $1 \%$ (Sigma) at $37{ }^{\circ} \mathrm{C}$ for $105 \mathrm{~min}$. After rinsing with water to remove excess of the enzyme mixture, the root tips were cut and mounted between the slide and cover slide in a drop of $45 \%$ acetic acid to increase the contrast of the chromosomes and cytoplasm. The squash was done with a match and the slides were subsequently frozen in liquid nitrogen to fix the chromosomes on slides. For the fluorescence observation of the chromosomes, the slides were washed successively by $1 \times \mathrm{SSC}, 2 \times \mathrm{SSC}$, PBS, 4B solution and 4 Tween for $15 \mathrm{~min}$.

\section{Fluorescence in situ hybridization (FISH)}

FISH on chromosomal DNA was carried out using three DNA probes, 5S rDNA (pTa 794) and 45S rDNA (pTa 71) isolated from Triticum aestivum, and $\mathrm{pSc} 119.2$ (repetitive DNA sequence) isolated from Secale cereale L. (Bedbrook et al., 1980; Gerlach, Bedbrook, 1979; Gerlach, Dyer, 1980).

The three DNA probes were labeled by nicktranslation: Biotin-16-dUTP for 5S rDNA and by Digoxigenin-11-dUTP for 45S rDNA and pSc119.2. Biotin and digoxigenin were detected by the antibody conjugated to the anti-streptavidin $\mathrm{Cy} 3$ (red) and antibody conjugated with anti-DIG fluorescein (green), respectively. The probing was made according to Kwiatek et al. (2013), using the two hybridization mixtures: the first $-160 \mu \mathrm{l}(20 \mu \mathrm{l} /$ slide) containing $5 \mathrm{~S}$ rDNA and 45S rDNA probes, and the second - $160 \mu \mathrm{l}(20 \mu \mathrm{l} /$ slide $)$ containing 5S rDNA and pSc119.2 probes. Chromosomal plaques with fluorescence signal were observed with an Olympus BX61 epifluorescence microscope (OLYMPUS corporation, Tokyo, JAPAN) equipped with a DP7 CCD camera. The captured images have been optimized for better contrast and brightness with Adobe Photoshop software (version 10.0). 
Table 1. Climatic and floristic characteristics of sampling sites of natural populations of Aegilops in Algeria

\begin{tabular}{|c|c|c|c|c|c|c|c|c|}
\hline Sites & Populations & Floristic characteristics & $\begin{array}{l}\text { Alt } \\
(\mathrm{m})\end{array}$ & $\begin{array}{c}\mathbf{M} \\
\left(\mathrm{C}^{\circ}\right) \\
\end{array}$ & $\begin{array}{c}\mathbf{m} \\
\left(\mathrm{C}^{\circ}\right) \\
\end{array}$ & $\begin{array}{c}\mathbf{P} \\
(\mathrm{mm})\end{array}$ & $\mathbf{Q}_{2}$ & Bioclimat \\
\hline \multicolumn{9}{|c|}{ Littoral } \\
\hline El-Kala 1 & g29 & Lawn of Poaceae, wayside & 30 & 27 & 2.8 & 1715 & 243.07 & Humid \\
\hline El-Kala 2 & g30 & Top of a hill with herbaceous plants & 10 & 27 & 2.8 & 1715 & 243.07 & Humid \\
\hline Seraidi & g24 & Lawn of Poaceae adjoining an olive grove (Olea europaea) & 200 & 26.2 & 3.8 & 919 & 140.72 & Sub-humid \\
\hline Skikda & g23 & $\begin{array}{l}\text { Edge of way adjoining a grove of olive and lentisk (Olea europaea- } \\
\text { Pistacia lentiscus) }\end{array}$ & 200 & 34.33 & 4.9 & 704 & 85.02 & Sub-humid \\
\hline Ançor & g2 & Lawn of Poaceae, roadside & 150 & 25.5 & 7 & 457 & 75.9 & Semi-arid \\
\hline Ain-Tassa & v1 & Herbaceous lawn & 100 & 25 & 6.60 & 437 & 81.46 & Sub-humid \\
\hline \multicolumn{9}{|c|}{ Tell Atlas } \\
\hline Zitouna & g28 & $\begin{array}{c}\text { Roadside adjoining a grove of olive and lentisk (Olea europaea - } \\
\text { Pistacia lentiscus) }\end{array}$ & 500 & 29 & 4.2 & 1773 & 245.21 & Humid \\
\hline Bougous & g27 & Grass lawn at the edge of cork oak forest (Quercus suber) & 250 & 29.6 & 4.8 & 1740 & 240.65 & Humid \\
\hline El-Afrine & g26 & Lawn of Poaceae under Eucalyptus camaldulensis & 300 & 29.5 & 4.7 & 1750 & 242.03 & Humid \\
\hline Souk-Ahras & g25 & Degraded maquis of cork oak (Quercus suber) & 500 & 24 & 6.3 & 729 & 78.4 & Sub-humid \\
\hline Constantine & g22 & Roadside under Eucalyptus camaldulensis & 600 & 32.8 & 2.8 & 515 & 58.88 & Semi-arid \\
\hline Mila & g21 & Herbaceous field & 450 & 30.7 & 2.5 & 603 & 73.34 & Sub-humid \\
\hline Sétif & g20 & Roadside in herbaceous field & 650 & 32.8 & 6 & 470 & 60.15 & Semi-arid \\
\hline Ourissia & g19 & Lawn of Poaceae bordering a forest of Pinus halepensis & 800 & 32 & 5.2 & 500 & 63.99 & Semi-arid \\
\hline Kherata & g18 & Roadside in herbaceous field & 600 & 32.3 & 4 & 1103 & 133.68 & Sub-humid \\
\hline Timzrite & g17 & Edge of fig grove (Ficus sp.) & 700 & 35.6 & 2.1 & 503 & 51.5 & Semi-arid \\
\hline Stita & n1-g16 & Lawn of Poaceae adjoining an olive grove (Olea europaea) & 300 & 28.9 & 6.3 & 1290 & 195.78 & Humid \\
\hline Ouaguenoune & n2 & Roadside bordering a field of wheat (Triticum durum) & 150 & 31.4 & 6.8 & 952 & 132.73 & Humid \\
\hline Taboukert & g13-n3-t3 & Herbaceous lawns on the bank of the Oued Sebaou River & 100 & 32.02 & 7.22 & 986 & 135.27 & Humid \\
\hline Timzguida & g14-n4 & $\begin{array}{c}\text { Roadside adjoining a grove of olive and lentisk (Olea europaea- } \\
\text { Pistacia lentiscus) }\end{array}$ & 300 & 30.7 & 3.9 & 1035 & 132.46 & Humid \\
\hline Tizi-Rached & g15-n5-t4 & Lawn of Poaceae adjoining an olive grove (Olea europea) & 400 & 30.0 & 4.7 & 1210 & 163.9 & Humid \\
\hline Iguenane & n6 & Roadside bordering a holm oak forest (Quercus ilex) & 600 & 32.0 & 2.7 & 1149 & 134.5 & Humid \\
\hline Ait-Meraou & g12-n7 & Edge of fig grove (Ficus sp.) & 650 & 31.6 & 2.9 & 1037 & 123.9 & Humid \\
\hline Benyenni & g11-n8 & Grass lawn at the edge of a cork oak forest (Quercus suber) & 850 & 32.6 & 2.8 & 1080 & 124.3 & Humid \\
\hline Tikjda 1 & g9 & Herbaceous lawn on flushed rocks & 1200 & 30.2 & 2.1 & 1100 & 134.2 & Humid \\
\hline Tikjda 2 & g10-v4 & Edge of Atlas cedar formation (Cedrus atlantica) & 1478 & 29 & 0.9 & 1190 & 145.3 & Humid \\
\hline Relizane & t2 & Understory of a forest of Pinus halepensis & 630 & 28.7 & 5.8 & 325 & 48.67 & Semi-arid \\
\hline Mascara & g4 & Understory of a forest of Pinus halepensis & 735 & 28.2 & 5.5 & 370 & 55.90 & Semi-arid \\
\hline Tessala 1 & v3 & Degraded maquis of cork oak (Quercus suber) on flushed rocks & 850 & 32.5 & 2.9 & 678 & 80.02 & Sub-humid \\
\hline Tessala 2 & g3-v2 & Degraded maquis of holm oak (Quercus ilex) on flushed rocks & 950 & 32.01 & 2.1 & 700 & 80.27 & Sub-humid \\
\hline Mansourah & g1-t1 & Forest of Pinus halepensis and Quercus ilex & 700 & 39.9 & 0.6 & 435 & 37.96 & Sub-humid \\
\hline Hamdania & g5 & Lawn of Poaceae on the riverbank & 450 & 31.6 & 3.3 & 755 & 91.50 & Sub-humid \\
\hline Benchicao & g6 & Roadside in a lawn of Poaceae & 1200 & 35 & 1.3 & 625 & 63.7 & Semi-arid \\
\hline Médea & g7 & Formation of Pinus halepensis & 600 & 32.2 & 2.7 & 800 & 93.3 & Sub-humid \\
\hline Berrouaghia & g8 & Roadside adjoining a holm oak forest (Quercus ilex) & 850 & 34.2 & 6 & 593 & 72.12 & Semi-arid \\
\hline \multicolumn{9}{|c|}{ Steppe highlands } \\
\hline Mesrane & g31 & Steppe with Caroxylon vermiculatum (Salsola vermiculata) & 1050 & 28.4 & 5 & 309 & 45.29 & Arid \\
\hline Guelt-Estel & g32 & Steppe with Lygeum spartum & 900 & 28.9 & 5.8 & 285 & 43.32 & Arid \\
\hline \multicolumn{9}{|c|}{ Saharan Atlas } \\
\hline Senalba & g33 & Forest of Pinus halepensis & 1350 & 33 & -1 & 402 & 43.08 & Semi-arid \\
\hline $\begin{array}{l}\text { Col des } \\
\text { Caravanes }\end{array}$ & g34-v5 & Clearing, with herbaceous lawn & 1300 & 36 & -1.5 & 352 & 34.99 & Arid \\
\hline Messaad & g35 & Clearing, with herbaceous lawn & 750 & 34.5 & -2 & 342 & 36.09 & Arid \\
\hline Taadmit & v6 & Clearing, with herbaceous lawn & 850 & 36 & -1.25 & 321 & 32.38 & Arid \\
\hline
\end{tabular}

Alt - altitude; $\mathbf{M}$ - average of the maximum temperatures of the hottest month; $\mathbf{m}$ - average of the minimum temperatures of the coldest month; $\mathbf{P}$ - average annual rainfall; Q2 - Emberger's coefficient; $\mathbf{g}$-Aegilops geniculata; $\mathbf{t}-$ A. triuncialis; $\mathbf{v}-$ A. ventricosa; n-A. neglecta. 


\section{Bioclimatic areas}

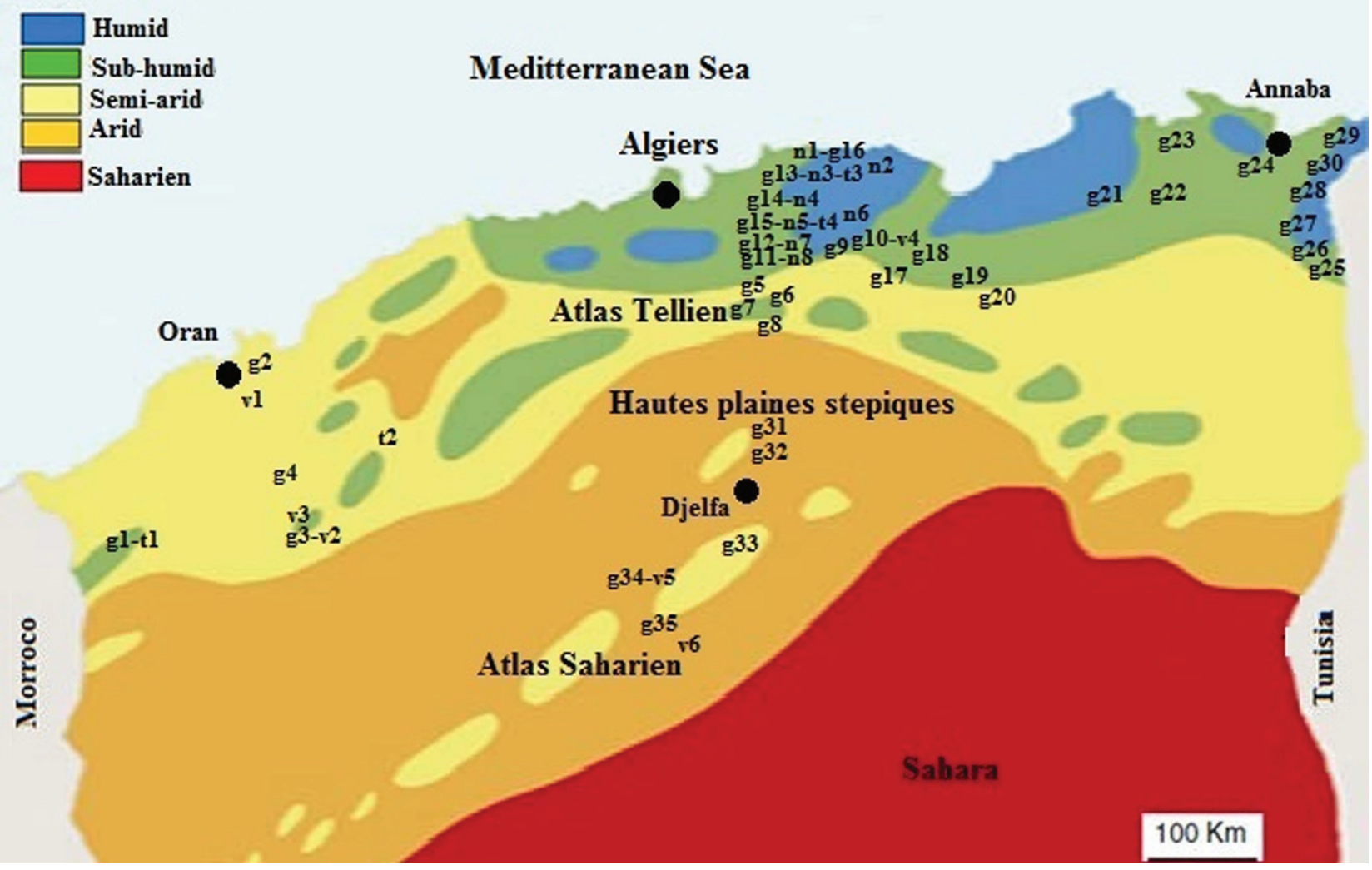

Fig. 1. Location of sampled populations of four species of Aegilops in Algeria (Aeg - A. geniculata, Aen - A. neglecta, Aev - A. ventricosa, and Aet - A. triuncialis). Bioclimatic limits are provided according to Stewart (1974)

Table 2. The rates of 5S, $\mathbf{4 5 S}$ and pSc 119 in four Aegilops species from Algeria

\begin{tabular}{|c|c|c|c|c|c|c|c|c|c|}
\hline \multirow{2}{*}{ Species } & \multirow{2}{*}{ Hybridization profile } & \multicolumn{3}{|c|}{$5 \mathrm{~S}$} & \multicolumn{3}{|c|}{$45 \mathrm{~S}$} & \multicolumn{2}{|c|}{ pSc 119} \\
\hline & & 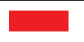 & ב & - & 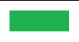 & - & - & $\bullet$ & 0 \\
\hline \multirow{5}{*}{ A. geniculata } & Aeg I & 4 & 10 & 2 & 4 & 6 & 2 & 1 & 1 \\
\hline & Aeg II & 4 & 4 & 0 & 4 & 8 & 0 & / & / \\
\hline & Aeg III & 4 & 4 & 0 & 4 & 10 & 0 & 1 & 1 \\
\hline & PrH.1 & I & 1 & I & I & l & 1 & 11 & 8 \\
\hline & PrH.2 & 1 & 1 & 1 & 1 & I & 1 & 11 & 6 \\
\hline \multirow{5}{*}{ A. ventricosa } & Aev I & 2 & 4 & 0 & 2 & 0 & 0 & / & / \\
\hline & Aev II & 2 & 4 & 0 & 2 & 4 & 4 & 1 & 1 \\
\hline & Aev III & 2 & 6 & 0 & 2 & 0 & 0 & 1 & 1 \\
\hline & PrH.1 & I & 1 & 1 & 1 & I & 1 & 8 & 10 \\
\hline & PrH.2 & I & 1 & 1 & I & I & 1 & 10 & 14 \\
\hline \multirow{3}{*}{ A. triuncialis } & Aet I & 4 & 10 & 0 & 4 & 4 & 0 & 1 & 1 \\
\hline & Aet II & 4 & 8 & 0 & 4 & 4 & 0 & 1 & 1 \\
\hline & PrH.1 & / & / & / & / & / & / & 21 & 16 \\
\hline \multirow{3}{*}{ A. neglecta } & Aen I & 4 & 6 & 2 & 4 & 4 & 2 & 1 & / \\
\hline & Aen II & 4 & 6 & 2 & 4 & 4 & 0 & 1 & 1 \\
\hline & PrH.1 & 1 & / & / & / & / & 1 & 28 & 23 \\
\hline
\end{tabular}

Украӥнський ботанічний журнал, 2021, 78(6) 

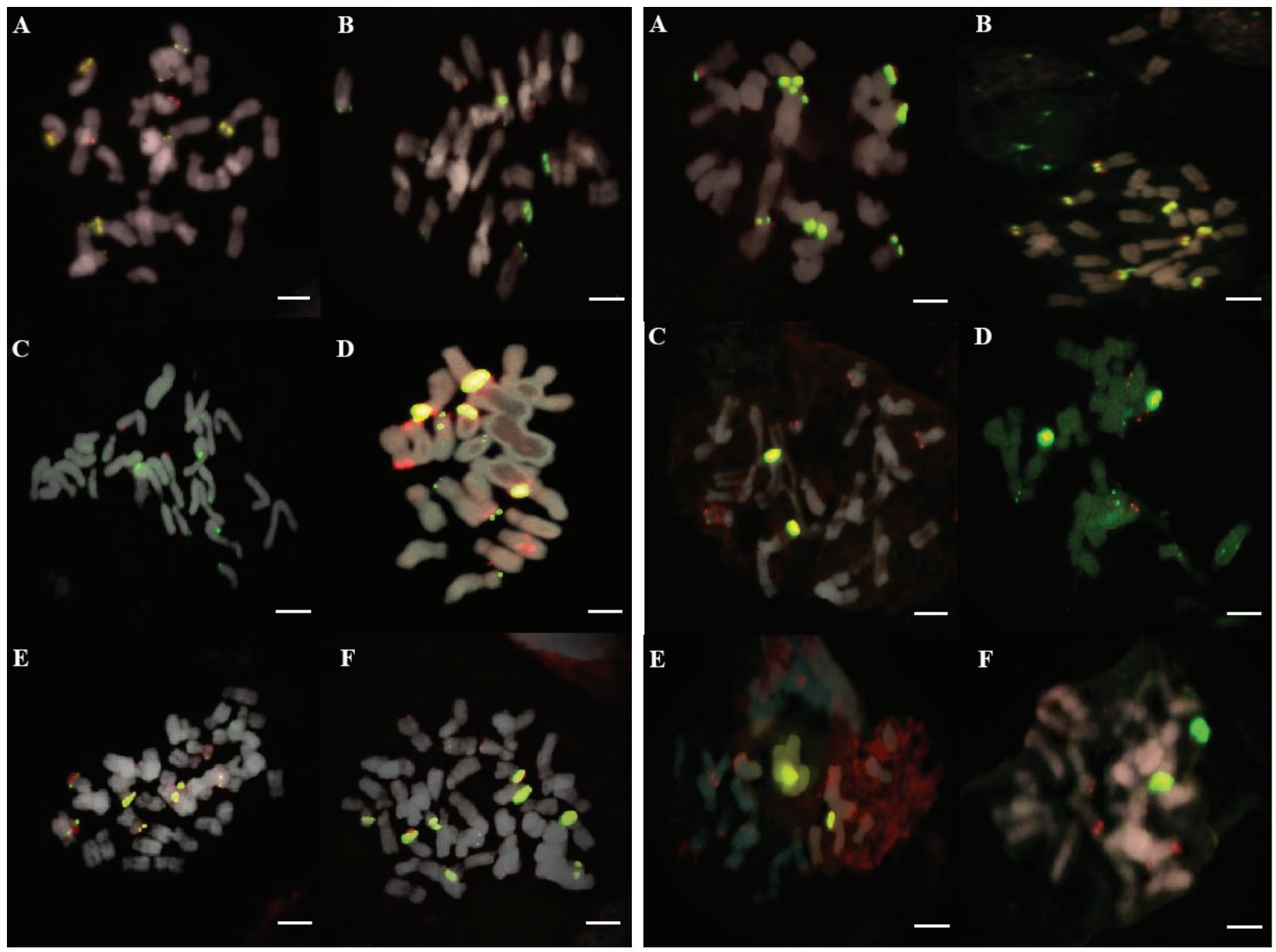

Fig. 2. FISH with rDNA 5S rDNA (Red) and 45S rDNA (Green) Fig. 3. FISH with 5S rDNA (Red) and 45S rDNA (Green) on on mitotic chromosomes of A. geniculata (A: Aeg I; B, C: Aeg II; mitotic chromosomes of A. triuncialis (A: Aet I, B: Aet II) and D: Aeg III) and A. neglecta (E: Aen I; F: Aen II). Scale bar: $10 \mu \mathrm{m}$ A. ventricosa (C: Aev I; D: Aev II; E, F: Aev III). Scale bar: $10 \mu \mathrm{m}$

\section{Results}

\section{Genetic diversity of the rDNA loci (5S and 45S)}

Analysis of the mitotic chromosomes, by FISH with two rDNA probes $5 \mathrm{~S}$ and $45 \mathrm{~S}$ (Table 2) revealed three hybridization patterns in the two species, A. geniculata (Aeg I, Aeg II, and Aeg III) and A. ventricosa (Aev I, Aev II, and Aev III), and two hybridization patterns in A. triuncialis (Aet I and Aet II) and A. neglecta (Aen I and Aen II) (Figs 2-4).

\section{Aegilops geniculata}

The Aeg I was found in the populations sampled in low altitudes with humid and subhumid bioclimates. It carries six chromosome pairs labeled as follows: the first pair, with two large 45S rDNA loci corresponding to active nucleolar organizing regions (NOR), two large 5S rDNA loci superimposed in the telomeric region of

the short arm, two minor 5S rDNA loci and two minor $45 \mathrm{~S}$ rDNA loci located in the subtelomeric region of the long arm; the second pair, with two large 45S rDNA loci (NOR) and two large 5S rDNA loci superimposed in the telomeric region of the short arm and two small $5 \mathrm{~S}$ rDNA loci in the subtelomeric region of the same arm; the third pair, is labeled with two small 5S rDNA loci in the telomeric region of the short arm; finally, the fourth, the fifth and the sixth pairs, were labeled each in the same way by two small $5 \mathrm{~S}$ rDNA loci and two small $45 \mathrm{~S}$ rDNA loci on telomeric region of the short arm.

The Aeg II distinguishes the populations sampled in the mountains and plains at medium altitude under subhumid and semi-arid bioclimates. It comprises six chromosome pairs labeled as follows: the first pair, with two large 45S rDNA (NOR) and two large 5S rDNA superimposed in the telomeric region of the short arm of 
chromosome 1 (in chromosome 2 these loci are deleted), and two minor $45 \mathrm{~S}$ rDNA in the secondary construction; the second pair, with two large $45 \mathrm{~S}$ rDNA (NOR) and $5 \mathrm{~S}$ rDNA superimposed in the telomeric region of the short arm and two small 5S rDNA and two small 45S rDNA in the subtelomeric region of the same arm; the third pair, labeled with two small $5 \mathrm{~S}$ rDNA in the telomeric region of the short arm; the fourth, fifth and sixth pairs, were similarly labeled each by two small $45 \mathrm{~S}$ rDNA loci in the telomeric region of the short arm.

The Aeg III characterizes the populations of mountains at high altitudes with humid bioclimate. It consists of the following six chromosome pairs: the first pair, with two large 45S rDNA (NOR) and two large 5S rDNA in the telomeric region of the short arm; the second pair, with two large 45S rDNA (NOR) and two large 5S rDNA superimposed in telomeric region of the short arm as well as two small 5S rDNA and two small 45S rDNA in the subtelomeric region of the same arm; the third, fourth and sixth pairs were labeled each by two small $45 \mathrm{~S}$ rDNA in the telomeric region of the short arm, while the fifth pair was labeled by two small 5S rDNA and two small $45 \mathrm{~S}$ rDNA on telomeric region of the short arm.

\section{Aegilops ventricosa}

The Aev I characterizes the populations sampled in the low altitudes with semi-arid bioclimate. These populations carried three chromosome pairs labeled as follows: the first pair with two small 5S rDNA loci in the subtelomeric region of the long arm; the second pair with two large 45S rDNA loci (NOR) and two large 5S rDNA loci superposed in the telomeric region of the short arm; the third pair labeled with two small 5S rDNA loci in the telomeric region of the short arm.

The Aev II was found in populations of the Tell Atlas Mountains at high altitudes under humid bioclimate. It contains seven chromosome pairs: the first pair, with two small 5S rDNA in the subtelomeric region of the long arm; the second pair, with two minor $45 \mathrm{~S}$ rDNA in the telomeric region of the short arm; the third pair labeled by two small 45S rDNA on telomeric region of the short arm; the fourth pair, with two small 45S rDNA in interstitial site on the long arm; the fifth pair labeled by two large 45S rDNA (NOR) and two large 5S rDNA superimposed in telomeric region of the short arm; the sixth pair, with two small 5S rDNA in the telomeric region of the short arm; the seventh pair labeled with two 45S rDNA minor loci in the subtelomeric region of the long arm.

The Aev III distinguishes populations of the Saharan Atlas Mountains at high altitudes under arid bioclimate.
It comprises three chromosome pairs labeled in the same way as Aev I and is differentiated by two small 5S rDNA loci in the subtelomeric region of the short arm of the second chromosomal pair.

\section{Aegilops triuncialis}

The Aet I was found in populations of steppe highlands with semi-arid bioclimate. It contains four chromosome pairs labeled as follows: the first and second pairs labeled by two large $45 \mathrm{~S}$ rDNA loci (NOR) and two large $5 \mathrm{~S}$ rDNA loci superposed in the telomeric region of the short arm and two small 5S rDNA loci in the subtelomeric region of the same arm; the third pair labeled with two small 5S rDNA loci and two small 45S rDNA loci in the telomeric region of the short arm; the fourth pair, with two small 5S rDNA loci and two small 45S rDNA loci in the telomeric region of the short arm and two small $5 \mathrm{~S}$ rDNA loci in the subtelomeric region of the same arm.

The Aet II characterizes populations sampled in low altitudes with humid bioclimate. It is constituted by four chromosome pairs labeled in the same way as Aet I, but is differentiated by the deletion of two small 5S rDNA loci of the first chromosomal pair.

\section{Aegilops neglecta}

The Aen I characterizes the populations sampled in mountains at high altitude under humid bioclimate. It contains six chromosome pairs labeled as follows: the first pair, with two large 45S rDNA loci (NOR) and two large 5S rDNA loci on telomeric region of the short arm; the second pair with two large 45S rDNA loci (NOR), two large 5S rDNA loci and two small 5S rDNA loci in telomeric region of the short arm; the third pair, with two small 45S rDNA loci in the telomeric region and two small 5s rDNA loci in subtelomeric region of the short arm; the fourth pair labeled in the same manner as the third pair, with the reverse localization of these two loci; the fifth pair, with two minor 5S rDNA loci on the long arm; the sixth pair with two minor loci of $45 \mathrm{~S}$ rDNA on the long arm.

The Aen II was found in the populations sampled at low altitudes under sub-humid bioclimate. It contains five chromosome pairs labeled in the same way as Aen I, but is differentiated by the deletion of the two $45 \mathrm{~S} \mathrm{rDNA}$ loci in the sixth chromosomal pair. 

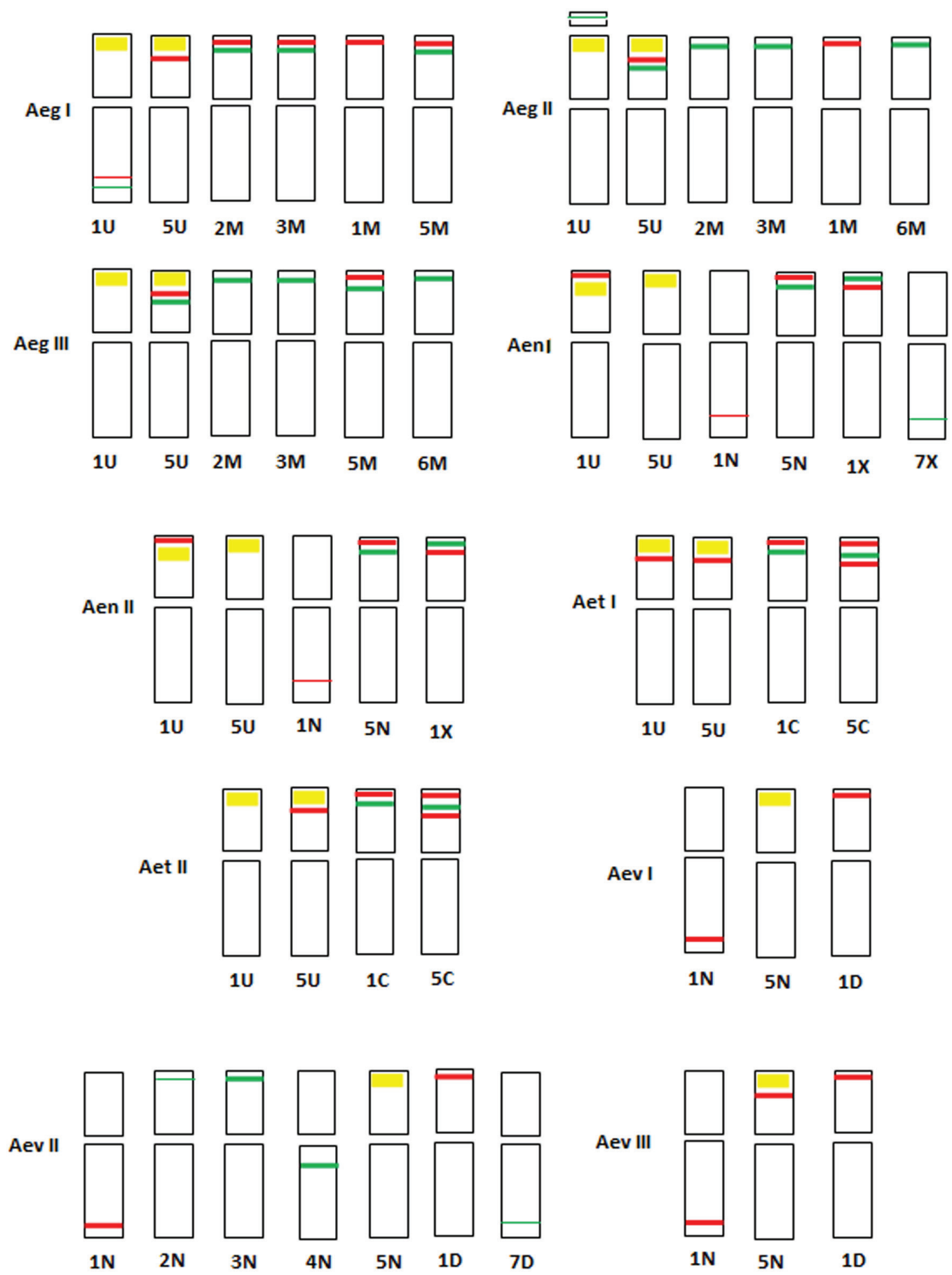

Fig. 4. Physical mapping (idiograms) showing distribution of 5S rDNA (red rectangle), 45S rDNA (green rectangle) and collocation of $5 \mathrm{~S}$ rDNA and 45S rDNA (yellow rectangle) on mitotic chromosomes of four species of Aegilops from Algeria 


\section{Genetic variability of the repetitive DNA sequence (pSc119.2)}

FISH with the pSc119.2 probe (Fig. 5, 6, Table 2) revealed two types of loci (large and small) distributed differently within the four studied species: two hybridization profile (PrH1 and PrH2) in each of the species, A. geniculata and $A$. ventricosa, while $A$. neglecta and $A$. triuncialis each show only one hybridization profile (PrH1).

\section{Aegilops geniculata}

The PrH1 was found in the populations sampled in low altitudes with humid and sub-humid bioclimates. It consists of nine chromosome pairs labeled with pSc119.2 probes as follows: 4 chromosome pairs (two small loci in the subtelomeric region of the short arm), 4 chromosome pairs (two large loci in the subtelomeric region of the short arm), and 1 chromosome pair (three large loci in the subtelomeric region of the short arm).

The PrH2 characterizes the populations of mountains at high altitudes with humid and arid bioclimate. It consists of seven chromosome pairs labeled with $\mathrm{pSc} 119.2$ probes as follows: 2 chromosome pairs (two small loci in the subtelomeric region of the short arm), 3 chromosome pairs (two large loci in the subtelomeric region of the short arm), 1 chromosome pair (three large loci in the subtelomeric region of the short arm), and 1 chromosome pair (two large loci in the subtelomeric region of the short arm and two small loci in the subtelomeric region of the long arm).

\section{Aegilops ventricosa}

The PrH1 distinguishes populations sampled in plains and mountains at medium altitude under sub-humid and semi-arid bioclimates. It has seven chromosomal pairs labeled by the pSc119.2 probe as follows: 1 chromosome pair (two small loci in the subtelomeric region of the long arm), 1 chromosome pair (two small loci in the subtelomeric region of the short arm), 1 chromosome pair (two large loci in the subtelomeric region of the long arm), 2 chromosome pairs (two large loci in the subtelomeric region of the short arm), 1 chromosome pair (two large loci in the subtelomeric region of the short arm and two small loci in the subtelomeric region of the long arm), and 1 chromosome pair (four small loci in the subtelomeric region of the long arm).

The PrH2 characterizes populations of Tell and Saharan atlas at high altitudes under humid and arid bioclimate, respectively. It is distinguished by ten chromosomal pairs marked with the pSc119.2 probe as follows: 1 chromosome pair (two small loci in the subtelomeric region of the long arm), 3 chromosome pairs (two small loci in the subtelomeric region of the short arm), 1 chromosome pair (two large loci in the subtelomeric region of the long arm), 3 chromosome pairs (two large loci in the subtelomeric region of the short arm), 1 chromosome pair (two large loci in the subtelomeric region of the short arm and two small loci in the subtelomeric region of the long arm), and 1 chromosome pair (four small loci in the subtelomeric region of the long arm).

\section{Aegilops triuncialis}

In this species, one hybridization profile (PrH1) was found. It includes eleven chromosome pairs labeled with the pSc119.2 probe as follows: 1 chromosome pair ( 2 small loci in the subtelometric region of the short arm), 3 chromosome pairs (2 large loci in the subtelometric region of the short arm), 1 chromosome pair (3 large loci in the subtelometric region of the short arm), 2 chromosome pairs $(2$ small loci in the subtelometric region of the short arm and 2 small loci in the subtelometric region of the long arm), 2 chromosome pairs (2 large loci in the subtelometric region of the short arm and 2 small loci in the subtelometric region of the long arm), 1 chromosome pair (2 large loci in the subtelometric region of the short arm and 2 large loci in the subtelometric region of the long arm), and 1 chromosome pair (2 large loci in the subtelometric region of the short arm, 2 large loci in the subtelometric region of the long arm and 2 small loci in the middle position of the long arm).

\section{Aegilops neglecta}

This species showed one hybridization profile (PrH1). It encompasses seventeen chromosome pairs labeled with the pSc119.2 in the telometric region (short and long arm), except the following four chromosome pairs: 1 chromosome pair (with 2 interstitial loci and 2 loci in the middle part of the long arm), 1 chromosome pair (with 2 loci in the subtelomeric region on the long arm), 1 chromosome pair (with 2 loci in the middle region and 2 subtelomeric loci of the long arm), and 1 chromosome pair (with 2 loci in the middle part of the long arm).

\section{Discussion}

The FISH profiling and physical maps (idiograms) enabled to identify and characterize the families of genes that encode the ribosomal DNAs (5S and 45S rDNA loci) and repetitive DNA sequence (pSc119.2) in the 

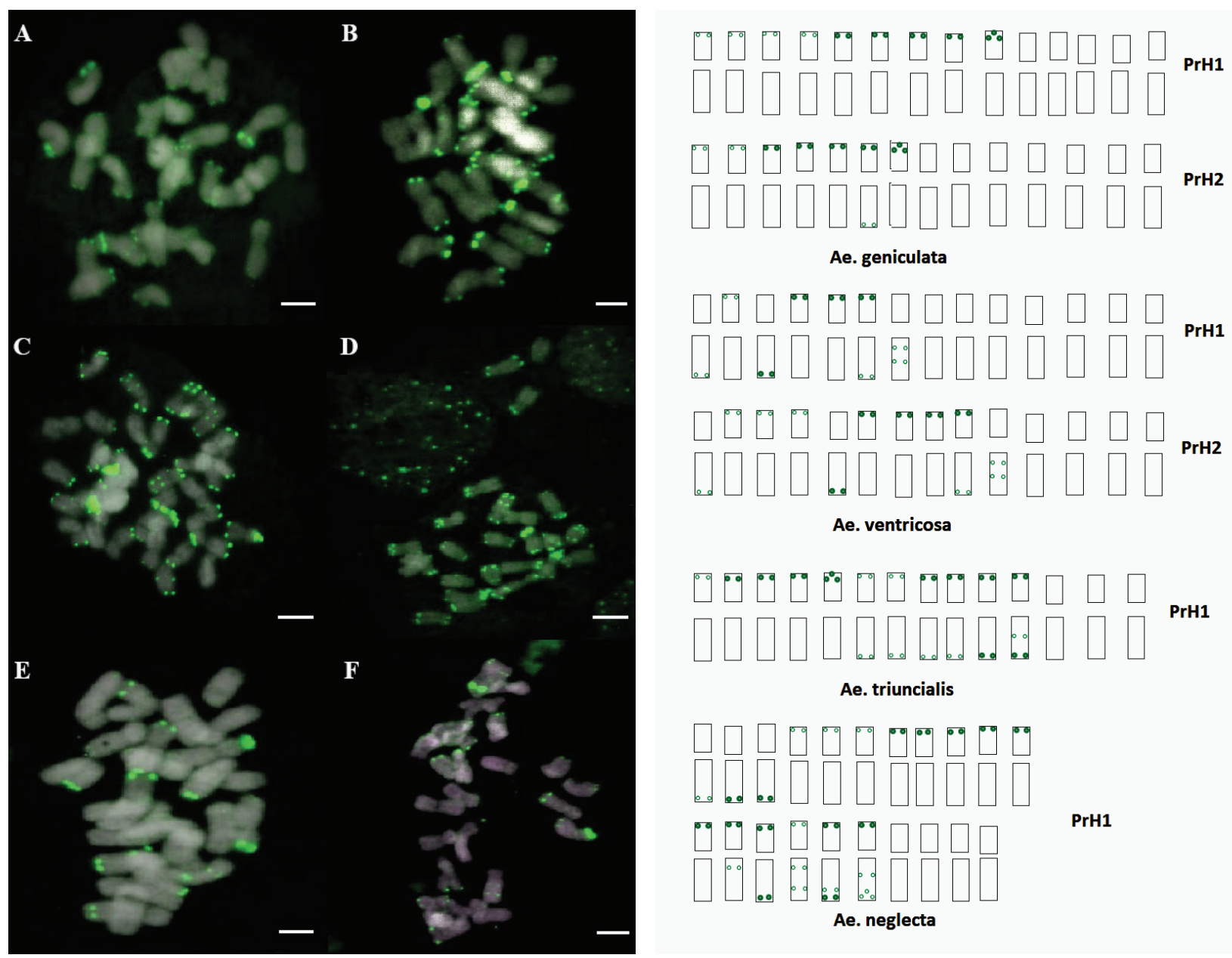

Ae. geniculata

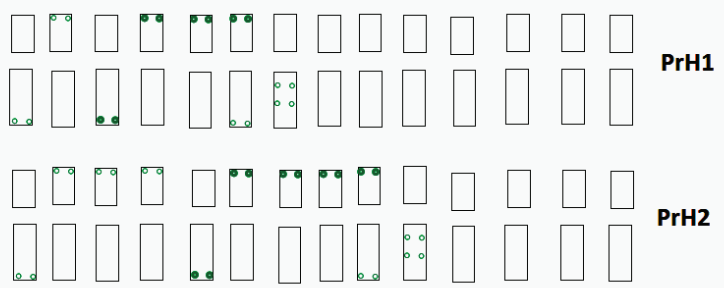

Ae. ventricosa

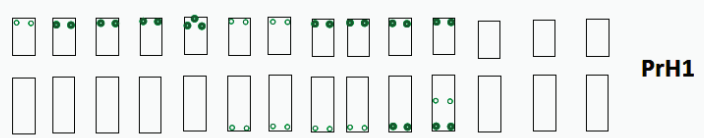

Ae. triuncialis

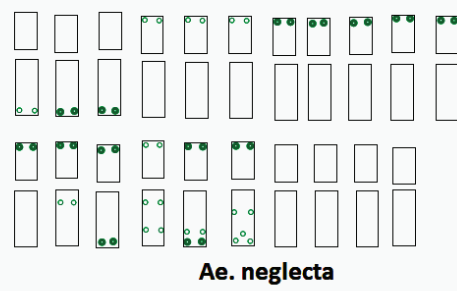

PrH1

Fig. 5. FISH on mitotic chromosomes with repetitive DNA Fig. 6. Physical mapping (idiograms) showing distribution of pSc119.2 (green circle): A. geniculata (A-B), A. neglecta (C), $A$. triuncialis (D) and $A$. ventricosa $(\mathrm{E}-\mathrm{F})$. Scale bar: $10 \mu \mathrm{m}$

populations of the four species of Aegilops sampled in different eco-geographical areas in Algeria.

According to the results obtained by Badaeva et al. (2002, 2004), the chromosomal pairs identified by $5 \mathrm{~S}$ and $45 \mathrm{~S}$ rDNA, correspond approximately to: $1 \mathrm{U}, 5 \mathrm{U}$, $1 \mathrm{M}, 2 \mathrm{M}, 3 \mathrm{M}, 5 \mathrm{M}$ and $6 \mathrm{M}$ in A. geniculata, $1 \mathrm{U}, 5 \mathrm{U}, 1 \mathrm{C}$, $5 \mathrm{C}$ in $A$. triuncialis, $1 \mathrm{~N}, 2 \mathrm{~N}, 3 \mathrm{~N}, 4 \mathrm{~N}, 5 \mathrm{~N}, 1 \mathrm{D}$ and $7 \mathrm{D}$ in A.ventricosa and $1 \mathrm{U}, 5 \mathrm{U}, 7 \mathrm{U}, 1 \mathrm{X}, 7 \mathrm{X}, 1 \mathrm{~N}$ and $5 \mathrm{~N}$ in A. neglecta. Indeed, the chromosomes we identified differ from those identified by these authors, who reported changes in chromosome structure between individuals of the same species sampled in different geographical sites.

In other polyploid species of the genus Aegilops, such as A. cylindrica Host (Linc et al., 2012) and A. crassa (Badaeva et al., 1998), the rDNA sequences that code for these same RNAs genes do not vary between repetitive DNA pSc119.2 (wide circle: large locus / slim circle: small locus) in four species of Aegilops

populations. At the same time, populations of the diploid species A. speltoides Tauch, considered to be a common ancestor of several species of the Sitopsis section, show a high variability in their cytogenetic structure revealed by a great polymorphism of the $5 \mathrm{~S}$ rDNA and $45 \mathrm{~S}$ rDNA sequences in relation to environmental conditions and changes in their ecological habitats (Belyayev, Raskina, 2013).

Some species of the family Poaceae, such as Festuca pratensis Huds. (now accepted as Lolium pratense (Huds.) Darbysh. or Schedonorus pratensis (Huds.) P.Beauv.), Lolium perenne L., Hordeum vulgare L. (Książczyk et al., 2010; Leitch et al., 1992), and some species of the family Rosaceae, such as species the genera Sanguisorba L., Agrimonia L., Rosa L., and Rubus L. (Mishima et al., 2002), show several patterns 
of hybridizations of the $5 \mathrm{~S}$ rDNA and $45 \mathrm{~S}$ rDNA loci expressed by the duplication or deletion of the copies of these genes in some chromosomal pairs.

The repetitive DNA sequence $(\mathrm{pSc} 119.2)$ revealed intraspecific differentiation of four species sampled at high altitudes, at low altitudes, and in the arid area by doubling and/or loss of some loci. This result agrees with those found by karyological analysis which showed that chromosome size varies significantly between the samples of these populations (Baik et al., 2017). Hence, these changes in the size and morphology of chromosomes have beneficial consequences on the evolutionary process and adaptation of species to eco-geographical conditions (Gorenflot, Raicu, 1980; Levin, 2002).

Abdolmalaki et al. (2019) and Parisod and Badaeva (2020) using FISH with repetitive DNA probes (GAA, pSc119.2, pTa535-1, pAs1-1) found a large intraspecific polymorphism of the hybridization patterns between different genotypes in each Aegilops species and a restructuring of the genome, which is associated with the processes of adaptation to the ecological condition and evolution of species and their chromosome structure.

Earlier, Salina et al. (2006) studied the evolution of DNA sequences (Spelt 1 and Spelt 52) repeated in tandem, in the species of Triticum and Aegilops, donors of the B genome, by FISH. Their data showed a large polymorphism in the number and patterns of hybridization of these sequences within species of each genus and determined phylogenetic relationships among species of the two genera. It has been proved that FISH is a good approach to characterize the genomes of interspecific hybrids between cultivated and related wild species, which has allowed understanding the role of cytogenetic markers in the function, structure and evolution of chromosomes and in plant breeding for the selection of suitable lines and populations (Cifuentes, Benavente, 2009; Kwiatek et al., 2013).

Meanwhile, the large-scale intraspecific and interspecific variability of the DNA loci and repetitive DNA sequence (pSc119.2) found in different cytotypes of the four species of Aegilops sampled in northern Algeria may be explained by the loss of genetic information by mutations, such as fissions and deletions, which have beneficial effects on the evolutionary process and adaptation (Gorenflot, Raicu, 1980; Soltis D., Soltis P., 1999). On the other hand, the structural diversity of chromosomes is often reflected in the phenotypic variability of several neopolyploid species (Ramsey, Schemske, 2002). This fact can favor adaptive evolutionary changes (Otto, Whitton, 2000) and would make it possible to adapt to eco-geographical conditions such as mountains at high altitudes and arid lands where some populations are sampled, thus promoting colonization of new ecological habitats (Levin, 2002).

\section{Conclusion}

Our results endorse that Algerian populations of Aegilops represent a polyploid complex with impressive genetic diversity and new landmarks of genes encoding rRNAs. Moreover, the north Algerian part has specific features and its transitional position between two contrasting areas (the desert to the south and the Mediterranean Sea to the north) offers the opportunity to study evolutionary trends of species and natural populations. We conclude that the environmental factors and geographical location might have an effect on the genetic structure and evolution of chromosomes. Furthermore, the cytogenetic markers are valuable tools in the identification and characterization of populations for assessing and enhancing plant genetic resources.

\section{Acknowledgements}

The present work has received a financial assistance from the University of Sciences and Technology Houari Boumediene (USTHB, Algiers, Algeria). It was conducted within the framework of the program "The assessment of morphological and genetic diversity of spontaneous species in Algeria" of the Biosystematics, Genetics and Evolution Team (Project: CNEPRU). The authors would like to thank Javier Narbona and Fernando Goméz-Aldecoa from the University of Complutense (UCM, Spain) for their technical assistance in FISH analysis.

\section{References}

Abdolmalaki Z., Mirzaghaderi G., Mason A., Badaeva E.D. 2019. Molecular cytogenetic analysis reveals evolutionary relationships between polyploid Aegilops species. Plant Systematics and Evolution, 305: 459-475. https://doi. org/10.1007/s00606-019-01585-3

Badaeva E.D., Friebe B., Gill B.S. 1996. Genome differentiation in Aegilops. 2. Physical mapping of 5S and 18S-26S ribosomal RNA gene families in diploid species. Genome, 39(6): 1150-1158. https://doi.org/10.1139/ g96-145 
Badaeva E.D., Friebe B., Zoshchuk S.A., Zelenin A.V., Gill B.S. 1998. Molecular cytogenetic analysis of tetraploid and hexaploid Aegilops crassa. Chromosome Research, 6: 629-637.

Badaeva E.D., Amosova A.V., Muravenko O.V., Samatadze T.E., Chikida N.N., Zelenin A.V., Friebe B., Gill B.S. 2002. Genome differentiation in Aegilops. 3. Evolution of the D-genome cluster. Plant Systematics and Evolution, 231: 163-190. https://www.jstor.org/ stable/23644354

Badaeva E.D., Amosova A.V., Samatadze T.E., Zoshchuk S.A., Chikida N., Zelenin A.V., Raupp W.J., Friebe B., Gill B.S. 2004. Genome differentiation in Aegilops. 4. Evolution of the U-genome cluster. Plant Systematics and Evolution, 246: 45-76. https://doi.org/10.1007/s00606-003-0072-4

Badaeva E.D., Dedkova O.S., Zoshchuk S.A., Amosova A.V., Reader S.M., Bernard M. Zelenin A.V. 2011. Comparative analysis of the $\mathrm{N}$-genome in diploid and polyploid Aegilops species. Chromosome Research, 19: 541-548. https://doi. org/10.1007/s10577-011-9211-x

Baik N., Maamri M., Bandou H. 2017. Karyological study and meiotic analysis of four species of Aegilops (Poaceae) in Algeria. Caryologia, 70(4): 324-337. https://doi.org/10. $\underline{1080 / 00087114.2017 .1387340}$

Bandou H., Rodriguez-Quijano M., Carrillo J.M., Branlard G., Zaharieva M., Monneveux P. 2009. Morphological and genetic variation in Aegilops geniculata Roth from Algeria. Plant Systematics and Evolution, 277: 85-97. https://doi.org/10.1007/s00606-008-0106-Z

Bedbrook R.J., Jones J., O'Dell M., Thompson R.J., Flavell R.B. 1980. A molecular description of telomeric heterochromatin in Secale species. Cell, 19: 545-560.

Belyayev A., Raskina O. 2013. Chromosome evolution in marginal populations of Aegilops speltoides: causes and consequences. Annals of Botany, 111(4): 531-538. https:// doi.org/10.1093/aob/mct023

Chennaveeraiah M.S. 1960. Karyomorphologic and cytotaxonomic studies in Aegilops. Acta Horti Gotoburgensis, 23: 85-178.

Cifuentes M., Benavente E. 2009. Wheat-alien metaphase I pairing of individual wheat genomes and $\mathrm{D}$ genome chromosomes in interspecific hybrids between Triticum aestivum L. and Aegilops geniculata Roth. Theoretical Applied Genetics, 119: 805-813.

Fernandez-Calvin B., Orellana J. 1990. High molecular weight glutenin subunit variation in the Sitopsis section of Aegilops. Implications for the origin of the B genome of wheat. Heredity, 65: 455-463.

Gerlach W.L., Bedbrook J.R. 1979. Cloning and characterization of ribosomal RNA genes from wheat and barley. Nucleic Acid Research, 7: 1869-1885.

Gerlach W.L., Dyer T.A. 1980. Sequence organization of the repeated units in the nucleus of wheat which contains 5S-rRNA genes. Nucleic Acid Research, 8: 4851-4865.

Giraldo P., Ruiz M., Rodríguez-Quijano M., Benavente E. 2016. Development and validation of chloroplast DNA markers to assist Aegilops geniculata and Aegilops neglecta germplasm management. Genetic Resources and Crop Evolution, 63: 401-407.
Gonzalez-Garcia M., Cuacos M., González-Sánchez M., Puertas M.J., Vega J.M. 2011. Painting the rye genome with genome-specific sequences. Genome, 54: 555-564.

Gorenflot R., Raicu P. 1980. Cytogénétique et évolution. Paris: Masson, 304 pp.

Haider N., Nabulsi I. 2008. Identification of Aegilops L. species and Triticum aestivum L. based on chloroplast DNA. Genetic Resources and Crop Evolution, 55: 537-549.

Kilian B., Mammen K., Millet E., Sharma R., Graner A., Salamini F., Hammer K., Zkan H. 2011. Aegilops. Chapter 1. In: Wild Crop Relatives: Genomic and Breeding Resources. Berlin; Heidelberg: Springer, pp. 1-76. https:// doi.org/10.1007/978-3-642-14228-4_1

Kimber G., Feldman M. 1987. Wild Wheat. An Introduction. Special Report 353, College of Agriculture, University of Missouri-Columbia, ii + 142 pp.

Książczyk T., Taciak M., Zwierzykowski Z. 2010. Variability of ribosomal DNA sites in Festuca pratensis, Lolium perenne, and their intergeneric hybrids, revealed by FISH and GISH. Journal of Applied Genetics, 51: 449-460. https://doi.org/10.1007/BF03208874

Kwiatek M.H., Wiśniewska H., Apolinarska B. 2013. Cytogenetic analysis of Aegilops chromosomes, potentially usable in triticale $(\times$ Triticosecale Witt.) breeding. Journal of Applied Genetics, 54: 147-155. https://doi.org/10.1007/ s13353-013-0133-5

Leitch I.J., Heslop-Harrison S. 1992. Physical mapping of the $18 \mathrm{~s}-5.8 \mathrm{~s}-26 \mathrm{~s}$ rRNA genes in barley by in situ hybridization. Genome, 35: 1013-1018

Levin D.A. 2002. The role of chromosomal change in plant evolution. New York: Oxford University Press, 226 pp.

Linc G, Friebe BR, Kynast RG, Molnar-Lang M, Köszegi B, Sutka J, Gill BS: Molecular cytogenetic analysis of Aegilops cylindrica Host. Genome 1999, 42: 497-503. https://doi.org/10.1139/g98-151

Mahjoub A., Abdellaoui R., Bannaceur M., Benbrahim N. 2010. Genetic diversity of Tunisian accessions of Aegilops geniculata Roth and durum wheats (Triticum durum Desf.) using RAPD markers. Acta Botanica Gallica, 157(1): 3-12.

Maire R. 1955. Flore de l'Afrique du Nord, vol. 3. Paris: Le Chevalier, pp. 65-69.

Mishima M., Ohmido N., Fukui K., Yahara T. 2002. Trends in site-number change of rDNA loci during polyploid evolution in Sanguisorba (Rosaceae). Chromosoma, 110: 550-558. https://doi.org/10.1007/s00412-001-0175-Z

Otto S., Whitton J. 2000. Polyploid incidence and evolution. Annual Review of Genetics, 34: 401-437.

Parisod C., Badaeva E.D. 2020. Chromosome restructuring among hybridizing wild wheats. New Phytologist, 226(5): 1263-1273. https://doi.org/10.1111/nph.16415

POWO. 2021-onward. Plants of the World Online. Facilitated by the Royal Botanic Gardens, Kew. Published on the Internet; http://www.plantsoftheworldonline.org/. Retrieved 23 December 2021. 
Quezel P., Santa S. 1962. Nouvelle flore de l'Algérie et des régions désertiques méridionales, vol. 1. Paris: Edition du CNRS, 558 pp.

Ramsey J., Schemske D.W. 2002. Neopolyploidy in flowering plants. Annual Review of Ecology and Systematics, 33: 589-639.

Rodriguez-Quijano M., Nieto-Taladriz M.T., Carrillo J.M. 2000. Polymorphism of high molecular weight glutenin subunits in three species of Aegilops. Genetic Resources and Crop Evolution, 48: 599-607.

Salina E.A., Lim K.Y., Badaeva E.D., Shcherban A.B., Adonina I.G., Amosova A.V., Samatadze T.E., Vatolina T.Y., Zoshchuk S.A., Leitch A.R. 2006. Phylogenetic reconstruction of Aegilops and the evolution of Tendem repeats in the diploids and derived wheat polyploids. Genome, 49: 1023-1035.

Sasanuma T., Chabane K., Endo T.R., Valkoun J. 2004. Characterization of genetic variation and phylogenetic relationships among diploid Aegilops species by AFLP: incongruity of chloroplast and nuclear data. Theoretical and Applied Genetics, 108: 612-618.

Senyaninova-Korchagina M. 1932. Karyo-systematical investigation of the genus Aegilops L. Bulletin of Applied Botany, Genetics and Plant Breeding. Series 2, 1: 1-90. [Селянинова-Корчагина М. 1932. Кариосистематическое исследование рода Aegilops. Труды по прикладной ботанике, генетике и селекичи. Серия 2, 1: 1-90].
Soltis D.E., Soltis P.S. 1999. Polyploidy: recurrent formation and genome evolution. Trends in Ecology and Evolution, 14: 348-352. https://doi.org/10.1016/s0169-5347(99)01638-9

Stewart P. 1974. Un nouveau climagramme pour l'Algérie et son application au barrage vert. Bulletin de la Société d'histoire naturelle de l'Afrique du nord, 65: 239-248.

Sun X., Qian W., Hao S., Zhang A., Wang D. 2006. Characterization of HMW glutenin subunits from Aegilops searsii and identification of a novel variant HBM glutenin subunit. Theoretical and Applied Genetics, 113(4): 631-641.

Van Slageren M.W. 1994. Wild Wheats: a monograph of Aegilops L. and Amblyopyrum (Jaub. \& Spach) Eig (Poaceae). ICARDA / Wageningen Agricultural University Papers, 94(7): 1-512.

Zaharieva M., Gaulin E., Havaux M., Acevedo E., Monneveux P. 2001. Drought and heat responses in the wild wheat relative Aegilops geniculata Roth: potential interest for wheat improvement. Crop Science, 41: 1321-1329.

Zhang X.Y., Wang R., Dong Y.S. 1996. RAPD polymorphisms in Aegilops geniculata Roth. (Ae. ovata auct. non L.). Genetic Resources and Crop Evolution, 43: 429-433.

Recommended for publication by O.K. Zolotareva

Баік Н., Банду У., Гонсалес Гарсія М., Бенавенте Е., Вега Х.М. 2021. Генетичне різноманіття рибосомальних локусів (5S і 45S рДНК) і повторюваної послідовності ДНК pSc119.2 у чотирьох видів Aegilops (Роaсеaе) 3 Алжиру. Украӥнський ботанічний журнал, 78(6): 414-425. [In English].

Кафедра біології, факультет природознавства та наук про життя, Університет Тахрі Мохаммеда в м. Бешар, Алжир: Н. Баік. Лабораторія біології та фізіології організмів, факультет біологічних наук, Університет наук і технологій Уарі Бумедьєн, Алжир, Алжир: Н. Баік, У. Банду. Кафедра генетики, біологічний факультет, Мадридський університет Комплутенсе, Іспанія: М. Гонсалес Гарсія, Х.М. Вега. Кафедра біотехнології, Вища технічна школа інженерів сільського господарства, Політехнічний університет, Мадрид, Іспанія: Е. Бенавенте.

Реферат. Продовжуючи наші попередні дослідження, ми провели каріологічне вивчення 53 популяцій чотирьох видів роду Aegilops (A. geniculata, A. triuncialis, A. ventricosa і A. neglecta), відібраних із різних за екологічними та географічними особливостями оселищ в Алжирі. Генетичну мінливість локусів хромосомної ДНК кожного зразка видів Aegilops виявляли методом флуоресценцентної гібридизації in situ з використанням трьох зондів: 5S рДНК, 45S рДНК і повторюваної ДНК (pSc119.2). Нами було встановлено, що два локуси рДНК (5S i 45S) гібридизувалися 3 деякими хромосомами і показали значний генетичний поліморфізм як у межах видів, так $\mathrm{i}$ між чотирма видами Aegilops, тоді як повторювані послідовності ДНК (pSc119.2) гібридизувалися 3 усіма хромосомами і відрізнялися в популяціях з гірських територій з вологим кліматом від популяцій зі степових районів із посушливим кліматом. Транспозиція фізичних карт досліджуваних локусів (5S pДНК, $45 \mathrm{~S}$ рДНК i pSc119.2) з картами інших колекцій виявила існування нових локусів у представників роду Aegilops 3 Алжиру.

Ключові слова: Aegilops, Алжир, генетичне різноманіття, генетичні ресурси рослин, екологічна географія, цитогенетичні маркери 